\title{
Handrest Device
}

National Cancer Institute

\section{Source}

National Cancer Institute. Handrest Device. NCI Thesaurus. Code C50276.

A part of a device designed to stabilize or support the hand. 